\title{
PHYTOCHEMICAL SCREENING AND ANTIMICROBIAL ACTIVITY OF BUNDUNG PLANTS EXTRACT BY DILUTION METHOD
}

\author{
Noval $^{1}$, Iwan Yuwindry ${ }^{1}$, Dahlia Syahrina ${ }^{1}$ \\ ${ }^{1}$ Sari Mulia University, JI. Pramuka No. 2, Pemurus Luar, Kec. Banjarmasin \\ Timur,Banjarmasin city, South Borneo 70238, Indonesia \\ email: novalhalim10@gmail.com
}

\begin{abstract}
Bundung plants (Actinuscirpus Grossus) are widely spread inBorneoand used by society empirically as antimicrobials. Nevertheless, the use of Bundung plantsas traditional medicine has not been equipped with convincing data,because there is no research that is related to the plants. In order to the use of the plants accountable, it is necessary to conduct research about phytochemical screening studies and tests the antimicrobial activity of ethanol extract of Bundung plants toStaphylococcus aureusandEschericia colibacteria. Moreover, extraction does withmaceration method. Secondary metabolite groups which are contained in the ethanol extract of Bundung plantswere determined qualitatively using several of phytochemical reagents. The result of phytochemical screening test showed that ethanol extract of Bundung plants contains a group of secondary metabolites; namely flavonoid, tannin, saponin, fenolik, steroid and terpenoid. The method that was used to test antimicrobial activity to Staphylococcus aureusandEschericia colibacteria was a liquid dilution method with variations in extract concentration of $0,5 \%, 1 \%, 2 \%, 4 \%$ and $8 \%$ by considering at the clarity of each sample. The result of antimicrobial activity of liquid dilution to bacteria had inhibition at all concentrations and the biggest inhibitory activity was shown at concentration $8 \%$ with the clearest level and the MIC grade of the test is at a concentration of $1 \%$.Based on thefindings, it can be concluded that ethanol extract of Bundung plantshas a potential of activities of an antimicrobial, especially from secondary flavonoid metabolites.
\end{abstract}

Keywords: Actinuscirpus Grossus, Phytochemical Screening, Antimicrobial.

\begin{abstract}
ABSTRAK
Tanaman Bundung (Actinuscirpus Grossus) banyak tersebar di Kalimantan dan banyak digunakan oleh masyarakat secara empiris sebagai antimikroba. Namun, pemanfaatan tanaman bundungsebagai obat tradisional belum dilengkapi data yang meyakinkan karena belum adanya penelitian terkait tanaman ini. Agar pemanfaatan tanaman ini dapat dipertanggung jawabkan maka diperlukan adanya penelitian skrining fitokimia sekaligus uji aktivitas antimikroba ekstrak etanol tanaman bundung terhadap bakteri Staphylococcus aureus dan Eschericia coli. Ekstraksi dilakukan dengan metode maserasi. Golongan senyawa metabolit sekunder yang terkandung pada ekstrak etanol tanaman bundung ditentukan secara kualitatif menggunakan beberapa pereaksi
\end{abstract}


fitokimia. Hasil uji fitokimia menunjukkan ekstrak etanol tanaman bundung mengandung golongan senyawa metabolit sekunder yaitu flavonoid, tannin, saponin, fenolik, steroid dan terpenoid. Metode yang digunakan untuk uji aktivitas antimikroba terhadap bakteri Staphylococcus aureus dan Eschericia coli adalah metode dilusi cair dengan variasi konsentrasi ekstrak $0,5 \%, 1 \%, 2 \%, 4 \%$ dan $8 \%$ dengan melihat tingkat kejernihan dari tiap sampel.Hasil uji aktivitas antimikroba dilusi cair terhadap bakteri memiliki daya hambat pada semua konsentrasi dan daya hambat terbesar ditunjukkan pada konsentrasi $8 \%$ dengan tingkatan yang paling jernih dan nilai KHM dari pengujian terdapat pada konsentrasi $1 \%$. Berdasarkan hasil tersebut, dapat disimpulkan bahwa ekstrak etanol tanaman bundung memiliki potensi aktivitas antimikroba khususnya dari senyawa metabolit sekunder flavonoid.

Kata Kunci : Actinuscirpus Grossus, Skrining fitokimia, Antimikroba

\section{INTRODUCTION}

Bundung plants (Actinoscirpus Grossus) are often used as woven material to make various kinds of handicrafts, can be used as pests trap at rice plants, natural wastewater treatment in companies, industries and households [1], [2]. Previous research has been conducted to the plant as a bioremidation filter [3]. However, as phytochemical test, there are still no studies found or published.

The plants are known to widely grow in Borneo land and empirically used as anti-diarrhea communities, anti-emetic and antimicrobial. But the ingredient in traditional medicine has not been equipped with data that scientifically convinces the content of the active compound that makes it efficacious as a drug, because research on it has never been done. In order the use of the plant parts as traditional medicines be able to bereasonable, scientific research such as research in the fields of pharmacology, toxicology, identification and active chemicals contained in plants is needed [4].

The plant, Actinocirpus grossus, in the form of upright strong, has many calves, with a long grain which leads to a small tuber, the stem triangles sharply with sides that are choked, smooth haired, $80-200 \mathrm{~cm} \times$ $5-10 \mathrm{~mm}$. Leaves in a rosette, such as a line, $50-80 \mathrm{~cm} \times 0.5-3 \mathrm{~cm}$, the bottom side just like triangles, the upper part curves shallow with a flat and very pointed tip, the edges are sharp haired. Terminal inflorescence, irregular, compound umbrella form; coarse axis of inflorescence, soft brushed hair, 4-17 cm in length; at the base there are a few protective leaves that are not of the same length, at 
least 2 of which are longer than inflorescence, $15-70 \mathrm{~cm}$ in length, spikelet in large numbers, solitary, sitting or stemmed, ovoid to elongated, pointed ends, with lots of flowers crowded end, $4-10 \times 3.5-4$ $\mathrm{mm}$. The ovoid fruit is reversed, with tapered, smooth, browned, triangular ends [5].

The discovery of various new drug compounds from natural materials show how important the role of secondary metabolites of plants as a source of medicinal raw materials. Biology activitiesare influenced by the types of secondary metabolites contained in it. They are also determined by the chemical structure of the compound. Structural units or molecular groups affect biological activities because they are related to the mechanism of action of compounds to receptors in the body [6]. Plants can be used as traditional medicine if they contain chemical compounds that have biological activities (bioactive substances). The biologically active compounds are secondary metabolites which include alkaloids, flavanoids, terpenoids, tannins, and saponins [7].

Antimicrobials are chemicals that are obtained/formed and produced by microorganisms. The substances have the power to inhibit the activity of other microorganisms, although in small amounts [8]. Antimicrobial activity tests can be carried out by using several methods, such as diffusion, dilution and bioautography methods. Diffusion and bioautography methods are qualitative techniques, shows the presence or absence of compounds with antimicrobial activity. On the other hand, the dilution method is used for quantitative, determine the Minimum Inhibition Level (MIC). In addition, the dilution method is used in research methods because it has the advantage that the method is able to show the number of certain drugs needed to inhibit (or kill) test microorganisms [9].

Based on the above explanation about the Bundung plant, it is necessary to do a phytochemical screening test and test the antimicrobial activity using dilution.

\section{METHODOLOGY}

\section{Materials}

The materials used in the study as a samplewas Bundung plant (Actinoscirpus Grossus), Staphylococcus aureus and Escherichia coli test bacteria. Supporting materials are Nutrient Agar, Nutrient Broth, Aquadest, $\mathrm{NaCl}$, Na. CMC, Dimethyl Sulfoxide 
(DMSO), Chloramphenicol, ethanol, chloroform, $\mathrm{NH} 3 \mathrm{FeCl} 3, \mathrm{H} 2 \mathrm{SO} 4$, Wagner, Dragendrof, and Mayer reagent, $\mathrm{Mg}, \mathrm{HCl}$ reagent concentrated, anhydrous acetic acid, gelatin, and methanol.

\section{Methods}

\section{Sample Processing}

The samples plants taken from the city of Banjarmasin, South Kalimantan. They are collected, cleaned and carried out in molding and dried at room temperature but still exposed by the sunlight. After drying, they are sorted again to eliminate unwanted impurities.

\section{Extraction by Maserati}

Making ethanol extract from the plant was by using the maceration method. The stages were as follows:

a. Add Simplicia of the plant (Actinoscirpus Grossus) to the percolator.

b. Put in ethanol into the percolator, soaks the simplicia until 2-3 cm high.

c. Keep the percolator, leave it for 3 days and stir it occasionally.

d. Take liquid out and filtere it.

e. The filtrate was then evaporated using a rotary evaporator until a thick extract was obtained.

\section{Phytochemical Test}

a. Alkaloid Identification

$1 \mathrm{ml}$ thin drop of extract of Bundung plant add to 5 drops of concentrated ammonia, then filtered, add 2 $\mathrm{ml}$ of $2 \mathrm{~N}$ sulfuric acids, then shake it until to the top and bottom layers are formed. The solution is divided into three parts which are inserted into the test tubes, the first tube is given 1 drop of mayer reagent. Positive alkaloids are characterized by the formation of deposits. The second tube is added with 1 drop of dragendr of, which is positively indicated by the presence of deposits. The third tube was added with 1 drop of Wagner reagent, positively the alkaloid was characterized by the presence of brown deposits [10].

b. Steroid and triterpenoid test

$1 \mathrm{ml}$ thin ofthe extract plant adds anhydrous acetic and sulfuric acid concentration if it is turned to a blue or green color indicating positive steroid, if it is purple or orange indicating as triterpenoid positive [10]. 
c. Phenoli test

3 thick drops of the plant (Actinoscirpus Grossus) are added to methanol and then stirred until homogeneous, after which $\mathrm{FeCl} 3$ was added. Positive is the presence of phenolics marked by the formation of yellow, green, orange or red [10].

d. Favonoids Test

$1 \mathrm{ml}$ of thick extract the plant is added 5 drops of ethanol and shaken until homogeneous. After that, added $\mathrm{Mg}$ powder and 5 drops of concentrated $\mathrm{HCl}$. Positive flavonoids are characterized by the formation of yellow, orange and red [10].

e. Saponin test

$1 \mathrm{ml}$ of the thick extract of the plantis added $2 \mathrm{ml}$ of aquades and shaken until homogeneous. After that it is heated 2-3 minutes, then cooled and shaken strongly. The positive presence of saponin is characterized by the formation of a stable foam for 30 seconds [10].

f. Tannin test

$1 \mathrm{ml}$ of the thick extract of the plant is added by 5 drops of $10 \% \quad \mathrm{NaCl}$ then shaken until homogeneous.Filtered andadd $1 \%$ gelatin and 10\% $\mathrm{NaCl}$. Positive presence of tannins characterized by the formation of deposits [10].

\section{Antimicrobial Activity Test}

a. Tool Sterilization

The tools were sterilized first, such glassware and the media in an autoclave at $1210 \mathrm{C}$ for 15 minutes. While the ose and tweezers are burned by burning directly on fire [11].

b. Medium

The jelly nutrient is weighed 2.3 grams and Nutrient Broth weighed is 8 grams. Both of them are then dissolved with 1 liter of distilled water. After all the ingredients are mixed, the medium is heated to dissolve completely, then sterilized by autoclaving at $1210 \mathrm{C}$ for 15 minutes [11].

c. Preparation of inoculum

Rejuvenation of Staphylococcus aureus and Escherichia coli bacteria are donein Nutrient medium to keep sterile. Test microbes are inoculated with one ose into the medium and incubated at 
$37^{\circ} \mathrm{C}$ for 24 hours (2). Test bacteria that have been rejuvenated for 24 hours in an incubator, each taken one ose and suspended into a $\mathrm{NaCl}$ solution, after which it is homogenized [12].

d. SolutionPreparation test

The inhibition test to ethanol extract of the plant is carried out by a liquid dilution method. The concentration of ethanol extract of the Bundung plant (Actinoscirpus Grossus) varies with a ratio of $50 \mathrm{mg}$ in $1 \mathrm{ml}$ of solvent which is $0.5 \%$, $100 \mathrm{mg}$ in $1 \mathrm{ml}$ of solvent that is $1 \%, 200 \mathrm{mg}$ in $1 \mathrm{ml}$ of solvent $2 \%, 400 \mathrm{mg}$ in $1 \mathrm{ml}$ the solvent is $4 \%$ and $800 \mathrm{mg}$ in 1 $\mathrm{ml}$ solvent which is $8 \%$. Each concentration of Nutrient Broth will be added to each concentration. The solvents used were $5 \%$ DMSO solvents. The positive control used was Chloramphenicol 1 $\mathrm{mg} / \mathrm{ml}$, while the negative control used was DMSO.

e. Making chloramphenicol positive control solution

$1 \mathrm{mg}$ of chloramphenicol is dissolved in $1 \mathrm{ml}$ of sterile distilled water. Then taken by way, as much as $0.5 \mathrm{ml}$ of chloramphenicol solution was added $0.1 \mathrm{ml}$ of test bacteria and in the ad. $0.4 \mathrm{ml}$ with Nutrient Broth [13].

f. Making negative control solutions

$0.5 \mathrm{ml}$ of Broth Nutrient in the test tube is added by 0.5 $\mathrm{ml}$ of DMSO solution. Then take $0.5 \mathrm{ml}$ was taken, 0.1 test bacteria were added and in 0.4 $\mathrm{ml}$ ad Nutrient Broth [13].

g. Determining antimicrobial activity

Liquid dilution method is done by preparing several test sterile tubes, the ethanol extract solution of the plant (Actinoscirpus Grossus) and test bacteria, medium solvent and test bacteria as negative controls, antibiotic solution (chloramphenicol) and test bacteria as positive controls. Furthermore, each tube is filled based on a predetermined concentration and added to the Nutrient Broth medium. Then all test tube tubes are incubated at $370 \mathrm{C}$ for 24 hours. Turbidity is observed to determine the antimicrobial activity of the ethanol extract of the Plant both on Staphylococcus aureus and 
Escherichia coli and then compared with positive controls (chloramphenicol), negative control (DMSO) and media control. The lowest concentration that does not show clarity is KHM.

\section{RESULTS AND DISCUSSION}

Phytochemical Screening Results

The results of screening studies of phytochemical compounds of the Plant should be seen at a table below:

Table 1. Results of chemical identification of ethanol extract of Bundung plants(Actinoscirpus Grossus)

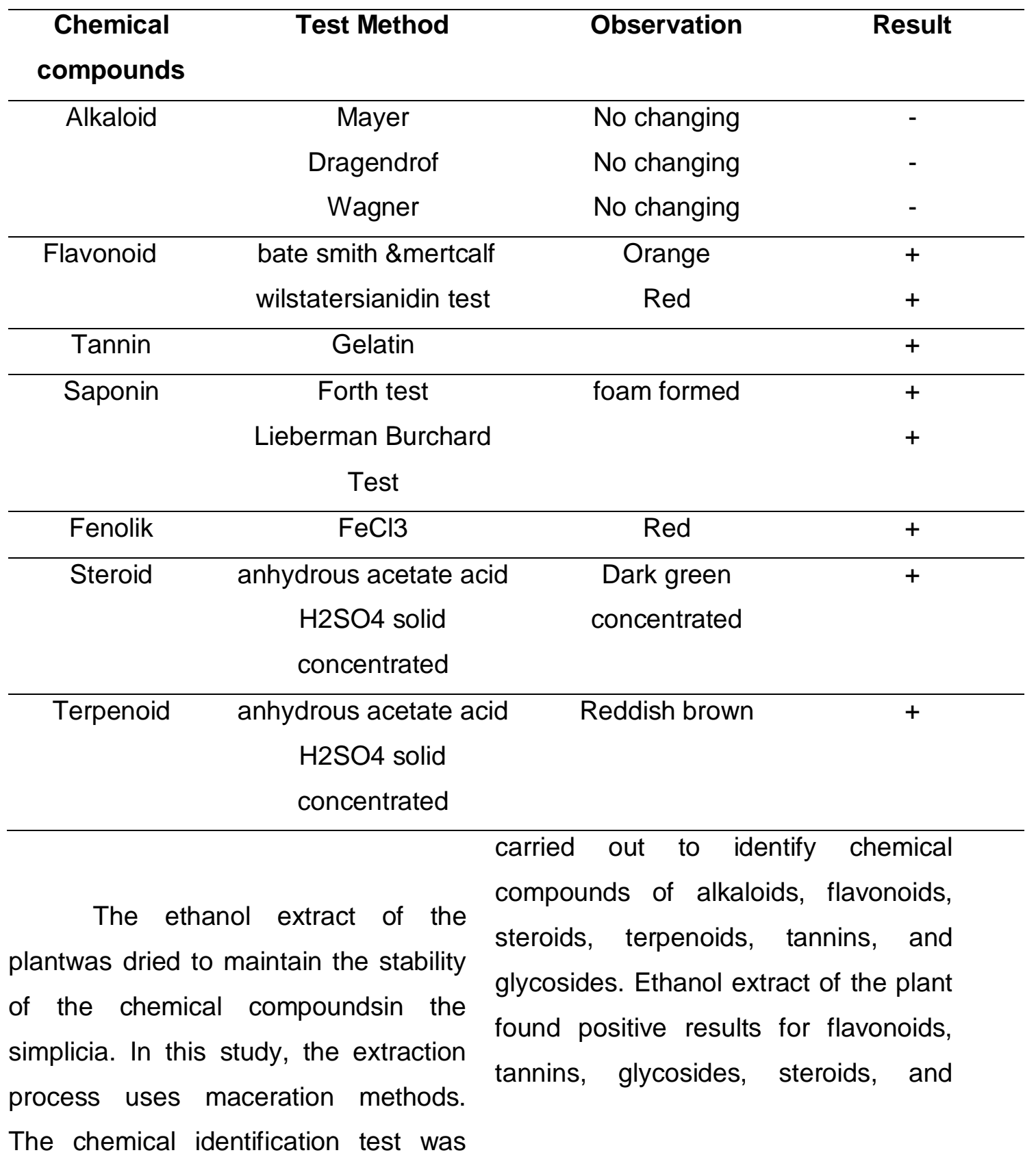


terpenoids. And negative results were obtained for alkaloids

Every chemical group has the potential to have pharmacological activities which are developed into a drug. From the plant, a lot of its chemical content is stated positively, such as flavonoids that have a carbon base frame where two benzene rings are bound to a chain of provinces. Some flavonoids have antiinflammatory, antihepatotoxic, antitumor, antibacterial and antioxidant properties [14].

Flavonoids are one of the secondary metabolites found in plants. This compound can be used as an antimicrobial, a wound infection medicine, anti-fungal, antiviral, anticancer, anti-tumor, anti-bacterial, antiallergic, cytostatic and antihypertensive [15].

Flavonoids are the largest group of phenol compounds found in nature. These compounds are red, purple and blue dyes and some ancient dyes found in plants. Flavonoids have a carbon base framework consisting of 15 carbon atoms, where two benzene rings (C6) are bound to one propane chain atom (C3) to form a C6-C3-C6 arrangement. This arrangement can produce three types of structures, 1,3diarilpropan or neuflavonoid. Flavonoid compounds consist of several types depending on the oxidation level of the propane chain from the 1,3diarilpropan system. Flavones, flavonols, and anthocyanins are the types found in nature, so they are often referred to as the main flavonoida. The such number of flavonoid compounds is caused by various levels of hydroxylation, alkoxylation or glycosidation of these structures. Classification of flavonoids based on the addition of oxygen chains and differences in the distribution of hydroxyl groups.

The flavonoids are polar compounds because they have a number of unsubstituted hydroxyl groups. Polar solvents such as ethanol, methanol, ethylacetate or mixtures of these solvents can be used to extract flavonoids from plant tissue [16].

\section{Antimicrobial Activity Test Results}

The test results of the antimicrobial activity of the ethanol extract of the plant on gram-positive Staphylococcos aureus and gramnegative Escherichia coli bacteria with concentrations of $0.5 \%, 1 \%, 2 \%, 4 \%$ and $8 \%$. The solvents used were $5 \%$ DMSO solvents, with a group of secondary flavonoid metabolites believed to function as antimicrobials. DMSO and Nutrient Broth medium were used as negative controls and 
Chloramphenicol $1 \mathrm{mg} / \mathrm{ml}$, Nutrient Broth and bacterial solution as positive controls. Chloramphenicol is a broadspectrum bacteriostatic antibiotic active against gram-positive and gramnegative aerobic and anaerobic organisms.

Determination of the Minimum Inhibitory Level (MIC) in the testing of antimicrobial activity was carried out using a liquid dilution method. The

Table. 2 Results Test of antimicrobial activity of ethanol extract of Bundung (Actinoscirpus Grossus) plants against Staphylococcus aureus and Eschericia coli bacteria by liquid dilution method

\begin{tabular}{ccc}
\hline Group & \multicolumn{2}{c}{ Value of Turbidity } \\
\cline { 2 - 3 } & Eschericia coli & $\begin{array}{c}\text { Staphylococcus } \\
\text { aureus }\end{array}$ \\
\hline Negative Control & 5 & 5 \\
Positive Control (Cloramfenikol) & 1 & 1 \\
\hline 5\%Concentrated & 5 & 5 \\
10\%Concentrated & 4 & 4 \\
20\%Concentrated & 3 & 3 \\
$40 \%$ Concentrated & 2 & 2 \\
$80 \%$ Concentrated & 1 & 1 \\
\hline
\end{tabular}

Remark :

Interval 1 : Clear

Interval 2 : fairly clear

Interval 3 : almost turbid

Interval 4 : fairly turbid

Interval 5 : turbid

Testing of antimicrobial activity $1 \%$ the sample was more clear than tested to agram-positive the concentration of $0.5 \%$, followed by Staphylococcus aureus bacteria at a concentrations of $2 \%, 4 \%$, and $8 \%$ concentration of $0.5 \%$ showed turbidity showed the results of the higher the in the sample, but at a concentration of concentration of the sample, the higher

parameters used to determine the clarity level of several sample concentrations seen after incubation at $370 \mathrm{C}$ for 24 hours. The Minimum Inhibitory Value (MIC) is determined by observing the smallest level that is still clear which indicates no bacterial growth. Based on the results of the study it is known that the MIC value at a concentration of $1 \%$ or $100 \mathrm{mg} / \mathrm{ml}$.

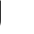


the level of clarity. The test results of antimicrobial activity on Escherichia coli bacteria showed that the gramnegative were not much different from the results of tests on Staphylococcus aureus bacteria that the MIC value at the concentration of $1 \%$, where the higher the concentration of the sample the higher the level of clarity. But at a concentration of $0.5 \%$, the test results on Staphylococcus aureus bacteria looked clearer than the test results on Escherichia coli bacteria, as well as the test results of $1 \%, 2 \%, 4 \%$, and $8 \%$.

The results of the liquid dilution method showed a difference in the clarity level of gram-positive bacteria Staphylococcus aureus and gramnegative Escherichia coli. The test results of gram-positive bacteria look clearer than the results of the test of gram-negative bacteria. It was due to differences in the constituent components of the cell wall between gram-positive bacteria and gramnegative bacteria. The cell wall of gram-positive bacteria has a simpler structure compared to the structure of more complex gram-negative bacteria. The complexity of the Escherichia coli bacterial cell wall is likely to inhibit the antimicrobial substances tested [17].

The main cell wall consists of peptidoglycan in gram-positive bacteria and teichoic acid. Peptidoglycan is a complex polymer consisting of a series of n-acetyl glucosamine acids and muramic n-acetyl acids which are arranged alternately outer membrane lipoproteins and lipopolysaccharide. The gram-negative cell lipopolysaccharide consists of a complex lipid called lipid $A$. The complex arrangement of gram-negative bacteria creates a significant obstacle to be penetrated by an antimicrobial, so the clarity of the test results of Bundung plant extracts against Escherichia coli is smaller than Staphylococcus aureus [17]. Based on the results of the antimicrobial activity test that the ethanol extract of the Bundung has the potential as an antimicrobial which is specifically found in the secondary group of flavonoid metabolites. In its activity, it is known that the ethanol extract of the Bundung plant is more potential as an antimicrobial in killing Gram-positive bacteria Staphylococcus aureus than gram-negative bacteria Ecshericia coli.

Based on research from Refrence [19], Soursop leaves (Annona muricata L.) contain secondary metabolites of flavonoids which function as antimicrobials. Bundung plants that have been tested also contain flavonoid metabolites, so it can be concluded that Soursop leaves and Bundung plants have the same 
potential as antimicrobials in the presence of secondary flavonoid metabolites. It can be concluded that the Bundung plant has the potential as antimicrobial, this research can proceed to the next stage so that it is expected to produce an antimicrobial product that can benefit the community.

\section{CONCLUSION}

Based on the results of the phytochemical screening test the ethanol extract of the Bundung plant (Actinoscirpus Grossus) positively contained the chemical composition of flavonoids, tannins, phenols, saponins, steroids, and triterpenoids. But it doesn't have alkaloid compounds. Ethanol extract of the Bundung plant has antimicrobial activity against grampositive bacteria. Staphylococcus aureus and gram-negative bacteria, However, the ethanol extract of the Bundung plant (Actinoscirpus Grossus) is more potential for gram-positive bacteria than gram-negative bacteria.

\section{ACKNOWLEDGMENTS}

The researcher would like to say his great appreciation to Republic of Indonesia Ministry of Research, "Kementrian Riset dan Tehnologi" for funding this research through "Hibah Penelitian Dosen Pemula" Grant Scheme in 2019.

\section{REFERENCES}

1. Yasril, A. G. (2009) 'Kemampuan Mansiang (Scirpus grossus) dalam Menurunkan Kadar BOD dan COD limbah Rumah Makan', Jurnal Kesehatan Lingkungan, 2(2), pp. 67-71

2. Komala, P. S. and Primasari, B. (2010) 'Pengolahan Limbah Cair Dengan Tumbuhan Scirpus Grossus L.F1) Waste Water Treatment Using Scirpus Grossus L.F'.

3. Sari, P. F. (2017) Efektivitas Mendong Sebagai Bioremediator Tanah Sawah Tercemar Kromium Oleh Limbah Industri. Universitas Sebelas Maret.

4. Lenny, S. (2006) 'Isolasi dan uji bioaktivitas kandungan kimia utama pudding merah (Gruptophyllumpictum. L Griff)', USU Reposotory.

5. Kostermans, A. J. G. . and Dekker, R. . (1987) 'The weeds: description, ecology and control'.

6. Lisdawati, V., Wiryowidagdo, S. L. and Kardono, B. S. (2007) 'Isolasi Dan Elusidasi Struktur Senyawa Lignan Dan Asam Lemak Dari Ekstrak Daging Buah Phaleria Macrocarpa', Jurnal dan Buletin Penelitian Kesehatan, 35.

7. Prashant and Al, E. (2011) 'Phytochemical screening and 
extraction', Internationale pharmaceutica sciencia, 1(1), pp. 1-9.

8. Waluyo, L. 2004. Mikrobiologi Umum. Malang. UMM Press

9. Jawetz, M. and Aldeberg (2007) Mikrobiologi Kedokteran. 23rd edn. Jakarta.

10. Harbone, J. B. (1987) Metode Fitokimia. Penuntut Cara Modern Menganalisis Tumbuhan. Terjemahan K. Padmawinata \& I. Soediro. Bandung: ITB.

11. Deby, A. M., Fatimawali and Weny, I. W. (2012) 'Uji Aktivitas Antibakteri Ekstrak Etanol Daun Mayana (coleus atropurpureus [1] benth) terhadap Staphylococcus

12. Dwyna, Z. and Johannes, E. (2012) 'Uji Efektivitas Ekstrak Kasar Alga Merah Eucheuma Cottonii Sebagai Antibakteri terhadap Bakteri Patogen'.

13. Wardani, R. ., Tjahjaningsih, W. and Rahardja, B. . (2012) 'Uji Efektivitas Ekstrak Daun Sirih Merah (Piper Rocatum) Terhadap Bakteri Aeromonas Hydrophila Secara In-Vitro', Jurnal IImiah Perikanan dan Kelautan, 4(1)

14. Achmad, S. A. (1989) Buku Materi Pokok Kimia Organik Bahan Alam. Edited by Universitas Terbuka. Jakarta: Depdikbud.
15. Sriningsih. 2008. Analisa Senyawa Golongan Flavanoid Herba Tempuyung (Sonchus arvensis $\mathrm{L}$ ) www.indomedia.com/intisari/1999/j uni/tempuyung.htm . Dikases tanggal 30 Januari 2011.

16. Rijke, E. (2005) Trace-Level Determination of Flavonoids and Their Conjugates Application ti Plants of The Leguminosae Family. Amsterdam University.

17. Nuaraina. 2015. Uji Aktivitas Antimikroba Ekstrak Daun Garcinia benthami Pierre Dengan Metode Dilusi. Skripsi. Jakarta: Fakultas Kedokteran dan IImu Kesehatan Universitas Islam Negeri Syarif Hidayatullah. Jakarta.

18. Friska, A. R., Haniastuti, T. and Utami, T. W. (2016) 'Skrining Fitokimia dan Aktivitas Antibakteri ekstrak etanol daun sirsak (Annona muricata, L) pada Streptococcus mutans ATCC 35688'. 